\begin{tabular}{|c|}
\hline \\
\hline \\
\hline \\
\hline 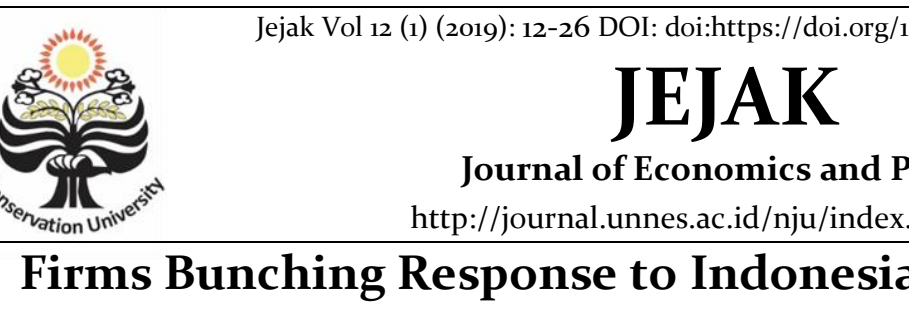 \\
\hline
\end{tabular}

\title{
Firms Bunching Response to Indonesian Income Tax Threshold
}

\author{
Ekananda Anggih Nurfauzi ${ }^{1 凶}$, Chaikal Nuryakin², Bramastia Candra Putra $^{3}$ \\ ${ }^{123}$ Faculty Economics and Business, Universitas Indonesia \\ Permalink/DOI: doi:https://doi.org/10.15294/jejak.v12i1.19344 \\ Received: October 2018; Accepted: January 2019; Published: March 2019
}

\begin{abstract}
Presumptive tax policy is implemented internationally in common in order to ease the SME's tax administration. Firms have an opportunity to respond or not to a certain tax policy in order to get lower tax burdens. There is a presumptive tax policy implemented in Indonesia which affects firms' behavior in gaining and reporting their incomes. Firms tend to choose to have their incomes below the threshold that has lower tax burdens. As a developing country, Indonesia has certain firms' charactheristics and systems that differs from developed country' firms so there is a necessity to know that the responses of Indonesian firms regarding the implementation of presumptive tax policy. This study aims to analyze firms' responses regarding presumptive tax implementation especially in Indonesia with a certain threshold of IDR 4.8 billion since 2013. This study uses the bunching estimation method dan firms' tax return data from 2011 to 2016, that differs from other studies in which use survey data. Our study concludes that the presumptive tax implementation based on turnover value induces negative bunching phenomenon in Indonesia due to the lower tax burden for firms whose turnover value is above the threshold. This negative bunching indicated by the results of significant bunching estimation analysis in the period after the presumptive tax policy implemented. In contrast to the developed country' firms, Indonesian firms tend to stay above the threshold, rather than below, to gain lower tax burden.
\end{abstract}

Key words : Bunching, Corporate income tax, Firm behavior; threshold.

How to Cite: Nurfauzi, E., Nuryakin, C., \& Putra, B. (2019). Firms Bunching Response to Indonesian Income Tax Threshold. JEJAK: Jurnal Ekonomi dan Kebijakan, 12(1), 153-167. doi:https://doi.org/10.15294/jejak.v12i1.19344

\begin{tabular}{ll}
\hline Corresponding author : & p-ISSN 1979-715X \\
Address: Jl. Margonda Raya, Pondok Cina, Depok City & e-ISSN 2460-5123 \\
E-mail: ekananda.nurfauzi@gmail.com &
\end{tabular}





\section{INTRODUCTION}

Scale based policies are commonly implemented in many countries. Its purpose is mainly to ease access for small individual enterprises or firms in order to expand their businesses. The most implemented policy based on business scale is presumptive tax policy. The presumptive tax policy has been seen to be implemented in almost all developing countries, included Indonesia. This policy is implemented on the sales/turnover base in common by defining a certain threshold to be applied. Intuitively, the basic idea of this policy is the broader said base, the harder it is to evade. It has been implemented in Indonesia for small and medium enterprises whose turnover is below IDR 4.8 billion in a year since 2013 . It potentially reduces the efficiency of taxing process and inhibits the pace of business development, though its purpose to spur the small business' growth (Harju, Matikka, \& Raunhanen, 2016). These minimum tax schemes provide an ideal setting for firms to estimate evasion responses to switch between the normal tax on profit base and presumptive tax on sales/turnover base using a bunching approach.

It is important to know why and how firms' respond to the minimum tax schemes' impact. This scheme induces a policy discontinuity predisposing firms' decision between production and sales/turnover reporting to authorized tax institutions (Almunia \& Lopez-rodriguez, 2018; Best, Brockmeyer, Kleven, Spinnewijn, \& Waseem, 2015; Gebresilasse \& Sow, 2015; Harju, Matikka, \& Rauhanen,
2016; Kleven \& Waseem, 2013; Onji, 2009; Saez, 2010). It gives different tax burdens between groups above and below the threshold under the same criteria such as firm scale, business sector, etc. (Adams \& Webley, 2001). The firms whose turnover actually above the threshold choose to stay below the threshold because the group above the threshold has greater tax burdens and more complicated tax treatments than the group below the threshold.

The existence of policy discontinuity around threshold creates certain condition called notch which happens when tax obligations increases significantly on certain earnings cutoff (Kleven \& Waseem, 2013). Taxpayers remain below the threshold in order to utilize the presumptive tax treatment if it has more benefit. This phenomenon known as bunching in previous studies is the behavior of taxpayers that remain to stay in certain area around threshold in regards of the higher benefit (Almunia \& LopezRodriguez, 2015; Best et al., 2015; Chetty et al., 2011; Fack \& Landais, 2016; Gebresilasse \& Sow, 2015; Harju, Matikka, \& Rauhanen, 2016; Kleven, 2016; le Maire \& Schjerning, 2013; Saez, 2010). Firms belonging to the group above the threshold must take into consideration the benefit of reporting sales/turnover above or below the threshold. Firms will also pay attention to the sense of fairness between that are above and below the threshold. firms that feel unfairly treated with the threshold will respond to that (Adams \& Webley, 2001). This decision reflects the firm's utility to maximize profit. A bunching phenomenon 
may occur around the threshold regarding the lower tax burden. However, it may also not exist due to honesty, the incapacity of avoidance, or else. because the level of firms' tax compliance also influenced by several intrinsic factors, such as honesty and risk behavior profile (Dwenger, Kleven, Rasul, \& Rincke, 2016).

Saez (2010) concludes in his study that most of firms choose to stay below the threshold to get lower tax burdens. There are some firm's real responses related to this kind policy discontinuity such as reducing its sales/turnover value by limiting its production capacities not over certain value or creating new entities to share its product capacities without proclaiming its related-ownership and deliberately lowering its reported sales/turnover value in tax return. Creating new entities or split the business size commonly used in Japan to avoid tax threshold (Yasuda, 2005; Onji, 2009). The first scheme consequently disturbs the economic efficiency. This behavior reflects the firm's retention of its business scale growth so that it creates an economic distortion because of the un-optimized utilization of its resources to maximize its sales/turnover and descent in tax revenue. The latter one is a kind of tax evasion in which firm deliberately underreports its reported sales/turnover value in order to gain lower tax burdens (Almunia \& LopezRodriguez, 2018). Tax evasion itself affects the optimality of tax revenues directly and the reality of economic condition.

Theoretically, firm tends to be inclined to certain conditions that have a lower tax burden. Firm would pay tax in the form of normal corporate income tax as $\mu=1$ with $\tau=\tau_{\pi}$ or presumptive tax as $\mu=0$ with $\tau=\tau_{y}$ where $\tau_{y}<\tau_{\pi}$. Taxable income is based on sales/turnover value as

$T\left(s, c^{\wedge}\right)=\max \left\{\tau_{\pi}\left[s-c^{\wedge}\right], \tau_{y} s\right\}$

Firms would shift between normal corporate income tax to presumptive tax if

$\tau_{\pi}[s-\hat{c}]=\tau_{y} s$ where $\hat{\pi} \equiv \boldsymbol{S}-\hat{\boldsymbol{C}^{S}}=\tau_{y} \tau_{\pi} \ldots$

It creates a fixed cutoff condition $\left(\tau_{y} / \tau_{\pi}\right)$ for gained profit as $\pi^{\wedge}$ (reported profit as a share of sales/turnover). If the gained profit is higher than the cutoff point, firms will pay tax in the form of normal corporate income tax and vice versa. If the firm's profit rate surpasses a certain threshold, both tax rate and tax base will change discontinuously, but its tax obligations will change continuously. This phenomenon is called a kink despite a notch though this kind of kink is different than what was worked on by Saez (2010) and Chetty et al. (2011) because there are changes in both tax rate and tax base. This combination of changes predisposes incentives of real output and compliances a differently - the marginal return to real output $1-\tau_{E}$ changes from 1 to $1-\tau_{y}$ when firms shift from normal corporate income tax to presumptive tax. The curve in fig. 1 shows the impact of a notch to firm's profit diagram. Firm's initial condition is a slope without a certain threshold. When a threshold policy is implemented, firms affected are firms with sales/turnover value of more than $s^{*}$. Firms with sales/turnover value of more than $s^{*}$ decrease their profit as the curve with the threshold. Bunching 
phenomenon is likely to happen to firms with sales/turnover value between $s^{*}$ and $S^{*}+\Delta S$ in response to preserving its profit at least equal to other firms below the threshold.

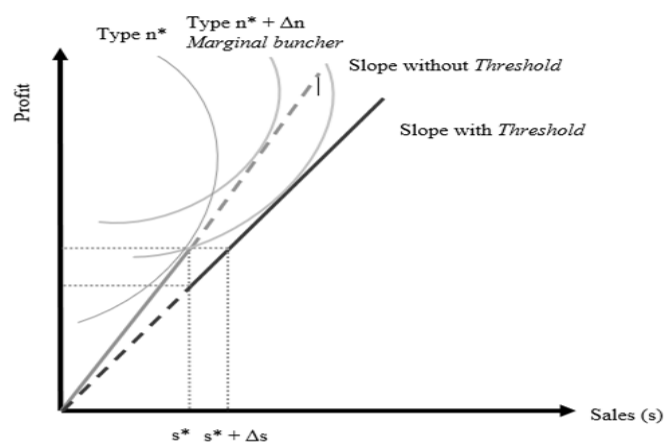

Figure 1. Profit Set Diagram

Regarding firm size distribution in fig. 2, the straight-line shows observed turnover distribution and the dotted line is counterfactual as if there is no certain threshold implemented. An excess mass happens when a certain threshold applied is shown as a spike line turnover distribution in the level of $s^{*}$. It comes from the lost turnover distribution above the threshold. A missing mass above the threshold is the area between the counterfactual distribution and observed turnover distribution $\left(s^{*}, s^{*}+\Delta s\right)$. Assuming smooth turnover elasticity and varies between firms, the distribution frequency slowly approaches the counterfactual curve above turnover of $s^{*}$. Then, $\boldsymbol{s}^{*}+\Delta \boldsymbol{s}$ represents the firm's turnover potentially to have a bunching phenomenon.

Because of the varied firm response, there are some firms that would stay in that area. There are two possible factors, such as the firm's honesty behavior and the inability of the firm itself (Almunia \& Lopez-rodriguez, 2018).

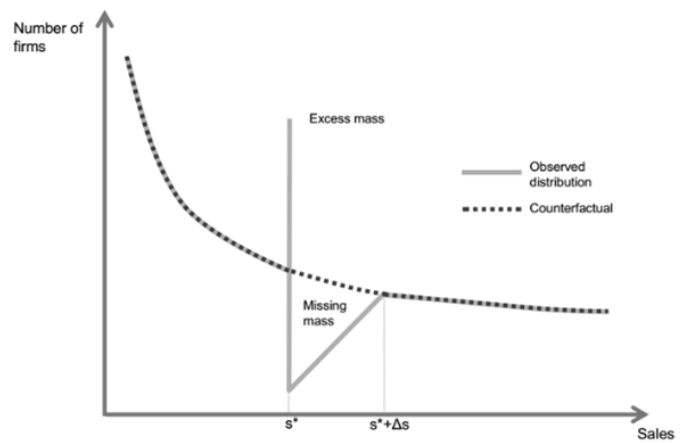

Figure 2. Firm Size Distribution:

Heterogenous Response

As a developing country, Indonesia's authorized tax institution, Directorate General of Taxes (DGT), has implemented the self-assessment system in reporting income tax since 1983. Its information/data collection is considered accurate unless DGT proves otherwise. In the selfassessment system, taxpayer determines his reported earning values and tax payable. This kind of system induces asymmetric information. It is susceptible to fraud, underreporting sales/turnover below its true number (Baumeister, 1982).

Small and medium enterprise (SME) has been considered to be a significant factor in spurring economic growth. In Indonesia, SME occupies more than $60 \%$ of gross domestic product in 2013 and makes up almost $99 \%$ of total Indonesian enterprises though most of them have not been registered as taxpayers. To simplify income tax calculation and regulations, the Indonesian government implements sales/turnover tax below a threshold instead of a pure profit tax. This scheme 

may retain both the efficiency of taxation and economic growth nationally, but its main purpose is to induce small enterprises' growth (Harju et al., 2016) and reduce Indonesian shadow economic rate.

Normal corporate income tax in Indonesia is $25 \%$ on profit base since 2009 . There is an incentive of tax rate reduction up to $50 \%$ of the normal tax rate $(12.5 \%)$ requiring that firm's annual turnover is below IDR 50 billion. Since 2013, the Indonesian government implemented a new presumptive tax scheme (1\%) based on sales/turnover value with the condition that the firm's annual turnover is less than IDR 4.8 billion and disregard its operational cost. Its legal basis is PMK193/2015. Its scheme aims to simplify the corporate income tax calculation and cut down SME tax burdens. For firms with a turnover value of more than IDR 4.8 billion in a year, they must pay the normal corporate income tax as implemented before.

The bunching phenomenon has been studied over years in different countries such as Almunia (2013), Almunia \& LopezRodriguez (2018), Bastani \& Selin (2014), and Liu \& Lockwood (2015) in which shown the same result. Most past studies concludes that there is a bunching phenomenon around certain threshold. Hsieh and Olken (2014) used Indonesian economic census data in 2006 and created a visual analysis in their study. It found no significant presence of firm response against said thresholds in Indonesia. Unlike the majority of research that uses survey data, this research used data sourced from firms' annual tax return reported to the DGT. This data is more relevant and reliable since it is reported by the taxpaying entity themselves. It also shows the actual tax reporting response rather than the usage of the census data because the census data does not show firms' real responses and misreporting sales/turnover regarding the presumptive tax policy below the threshold. This analysis is done during two periods (before and after presumptive tax scheme implementation) at a certain threshold point so that it may capture a clearer picture on the potential existence of the bunching phenomenon regarding tax policy implementation based on firm scale.

Using bunching estimation method used by Kleven and Waseem (2013) and Chetty et al. (2011), at a threshold of IDR 4.8 billion in 2013-2016, there is a negative bunching phenomenon where firms' distribution is beyond the threshold. It implies that those firms overreport sales/turnover value more than its true value to gain less tax burden than it should. There no positive bunching phenomenon in the area below the threshold, but there significant bunching phenomenon in the opposite direction. This study shows different result compared than the other studies in other countries. Bunching responses indicate that the threshold becomes a barrier for small enterprises' growth because of the increase of the threshold in the preceding period, while negative bunching even gives an incentive for firms to increase its sales/turnover over the true responses or overreporting. These responses raise the question of misjudgment of policy making because the 

data used are not true values. In section 2 we discuss on the research method that employ, consisting of conceptual framework used in previous literature, corporate income tax policy in Indonesia, relevant existing empirical literature to define our empirical strategy, and data used in this study. Section 3 discusses the empirical result and its discussion. Lastly, Section 4 will conclude the study.

\section{RESEARCH METHOD}

Understanding firm's behavior around a certain threshold can be attained by using the bunching estimation method that has been used in previous studies by Emannuel Saez (2010), Chetty et. al. (2011), Kleven \& Waseem (2013), Almunia (2013), Gebresilasse \& Sow (2015), Harju et al. (2016), Almunia \& Lopez-Rodriguez (2018), and Best \& Kleven (2018). This estimation method is employed by comparing the distribution of firms' turnover around factual threshold and based on estimation (counterfactual). Based on previous literature, there would be some buildups of firms' reporting regarding its turnover in a certain area such as below or above threshold depending on where the lower tax burden is.

To estimate firms' responses, the estimation of the degree of bunching is employed around a certain threshold. First, the calculation of counterfactual distribution without threshold policy is employed, then compared to actual observed density distribution. This method is similar to difference-indifference method that commonly used in policy impact evaluation (Clair \& Cook,
2015). The counterfactual response is estimated by using a polynomial equation without data in a range of $\left[s_{L}, s_{U}\right]$ around threshold $s^{*}$. If its distribution is grouped in term of a bin (width of $w$ ), the polynomial regression estimation is shown in equation (3) as follows :

$C_{j}=\sum_{i=0}^{q} \beta_{i} \cdot\left(s_{j}\right)^{i}+\sum_{i=s_{L}}^{s_{U}} \gamma_{i} \cdot 1\left[s_{j}=1\right]+\varepsilon_{j}(3)$

$C_{j}$ is the sum of firms in bin $j, s_{j}$ is the median of firms' turnover in each bin, $q$ is the polynomial order, $s_{L}$ and $s_{U}$ are the lower limits and the upper limit of the excluded area, and $\gamma_{i}$ is the intercept shifters for each bin in the affected area. The coefficient of its regression estimation is used as a value to estimate the counterfactual distribution of firms' turnover. The data of the affected area is excluded to omit the disturbance around the threshold.

$\widehat{C}_{J}=\sum_{i=0}^{q} \widehat{\beta}_{l} \cdot\left(s_{j}\right)^{i}$

To estimate excess of bunching mass $\left(B_{n}\right)$ and missing mass $\left(H_{n}\right)$ around a certain threshold, the comparison between counterfactual density and observed distribution in the area of $\left[s_{L}, s_{U}\right]$ is employed as follows.

$\widehat{B_{n}}=\sum_{s_{L}}^{S_{L}} \mid C_{j}-\widehat{C_{J}}$

$\widehat{H_{n}}=\sum_{S *}^{s_{U}}\left|\widehat{C}_{J}-C_{j}\right|$

Valid estimation of an excess of bunching assumes that this excess mass must same as the missing mass (Kleven \& Waseem, 2013) so that the assumption of $\widehat{B}_{n}=\widehat{H}_{n}$ must be used. Based on the assumption, Chetty et al (2011) define empirical estimation of $b$ as excess mass 
around certain threshold relative to the mean of counterfactual turnover density.

$$
\hat{b}=\frac{\hat{B}_{n}}{\left[\frac{1}{1+\left(s^{*}-s_{L}\right) / w}\right] \sum_{j=s_{L}}^{S_{L}} \widehat{\beta}_{l} \cdot\left(s_{j}\right)^{i}}
$$

There are some assumptions employed in this bunching approach, which are as follows : Counterfactual distribution is in the form of a smooth curve and as a polynomial function, The form of counterfactual distribution is downward sloping from a high value of the firm's turnover to low value of firm's turnover; and, There is data aggregation bias because of the heterogeneity of elasticity in response to threshold policy so that this bunching approach identifies the mean values of response behavior among different elasticity responses.

Using the micro data from income tax returns reported by firms in Indonesia to DGT, the estimation analysis is run for two terms, first two years (2011 - 2012) before presumptive tax policy applied, and second, four years (2013 - 2016) after presumptive tax policy applied with a threshold point (IDR 4.8 billion). Twoperiod analysis is used to ascertain the impact of the presumptive tax policy with threshold point implementation. besides being carried out periodically, the analysis is carried out on an annual basis to find out patterns and phenomena in detail every year. The data used in this research covers all business categories spread throughout Indonesia, though the size of the business of the registered taxpayer in DGT administration has turnover value not more than IDR 4.8 billion so the data can represent the situation in Indonesia.

\section{RESULTS AND DISCUSSION}

The shown result in this part is the result of bunching estimation method proposed by Chetty (2011) as used in the previous studies. In the figure, the dots show the actual firms' distribution in Indonesia based on their turnover. While the smooth line is the counterfactual firms' distribution in Indonesia as if there is no kind policy implemented and affecting the firms' response. Emperically, bunching estimation is able to be used to find out the significant differences between the actual and the counterfactual firms' distribution and the affect of a certain policy into firms' behavior.

Firms size distribution as shown in figure 3 and 4 indicate that Negative bunching phenomenon occurs around the threshold (IDR 4.8 billion). This 'negative' term means that it happens above the threshold. Firms distribution accumulated above the threshold differs from the original theory in previous literature that bunching phenomenon usually occurs below a certain threshold because of its benefit.

The Indonesian case shows that normal corporate income tax relatively has a lower tax burden than presumptive tax, and it's shown by the negative bunching phenomenon. Before the presumptive tax policy implemented as shown in Figure 3, there is no spesific pattern in firms' sales distribution around IDR 4.8 billion. The distribution of firms tends to spread out and there is no proclivity around certain turnover value. It is caused by the absence of a certain tax policy for this area. 
Firms tend to operate normally and be unaffected by certain policy. Indonesian firms distribution pattern is consistent with Hsieh and Olken (2014) study that firms' distribution based on turnover value smoothly declining along with turnover value.

To improve SME's tax compliance and to formalize more SME's industry into tax administration, the presumptive tax scheme with certain threshold is applied. Based on Figure 3 SME's taxpayers that has been administrated in Indonesian tax system, still does not know about bookkeeping and has low tax compliance. Still, there has a lot of SME's industry which does not know about tax obligation.

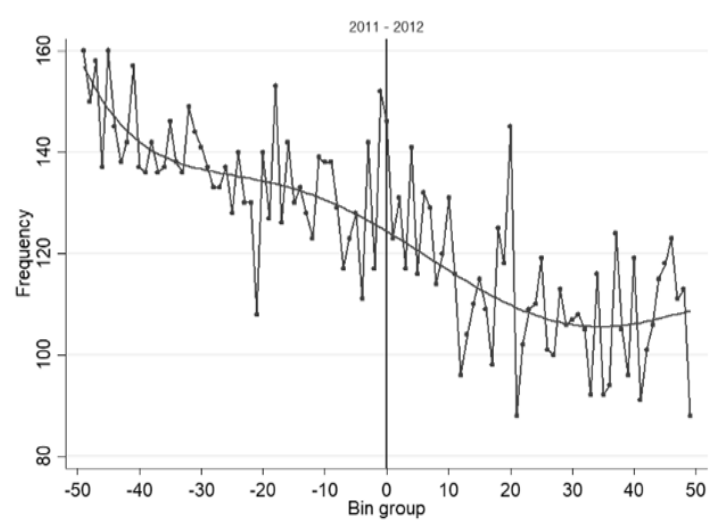

Figure 3. Firms Turnover Distribution in Pooled Data around IDR 4.8 Billion Threshold 2011-2012

After the presumptive tax policy implemented as shown in Figure 4, there is certain pattern in firms' sales distributions around IDR 4.8 billion. Firms tend to gather around the turnover distribution little higher than IDR 4.8 billion. Firms tend to have same response by reporting its turnover a liitle bit higher than IDR 4.8 billion. This kind of response differs from other countries' responses. distribution of firms' turnover value in other countries tend to gather around a little bit lower than certain threshold, called bunching, though in Indonesia they tend to gather around a little higher than certain threshold, contrary to the common response or called negative bunching. The number of firms that tend to do negative bunching is as wide as the differences between the actual and the counterfactual distribution in the area between threshold and upper limit.

SME's taxpayers that has turnover value not more than IDR 4.8 billion a year, have a tax obligation and administration to be fulfilled. They are taxed by the new presumptive tax scheme and have to held bookkeeping for tax reporting. Thus, Indonesian tax authorized provides more services for this administrative obligation. On the other hand, SME's taxpayers see this tax scheme would give them more financial burden in order to held bookkeeping even it is important for them.

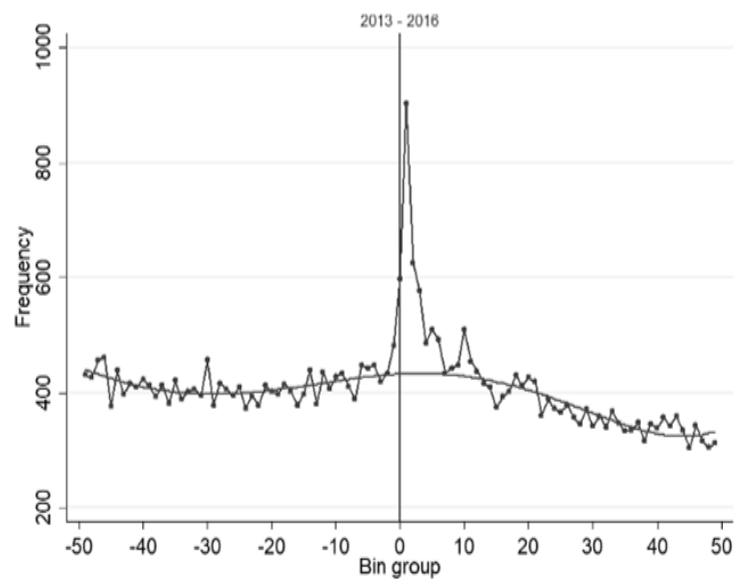

Figure 4. Firms Turnover Distribution in Pooled Data around IDR 4.8 Billion Threshold 2013-2016 

If we analyze the graphic annually, it has known since when the negative bunching phenomenon happens in Indonesia. The pattern of firms' turnover distribution in the year of 2011 and 2012 as shown in Figure 5 and 6, there is no specific pattern in firms' turnover distribution around IDR 4.8 billion.

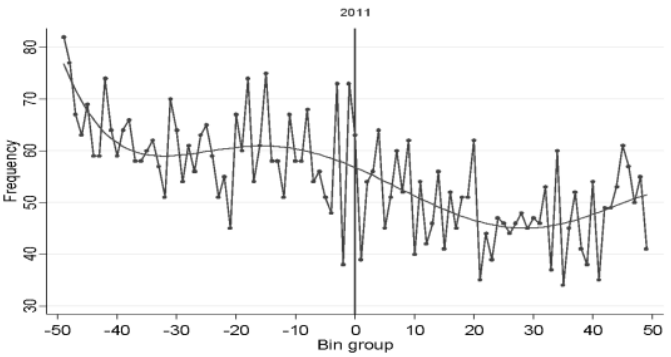

Figure 5. Annual Firms Turnover Distribution around IDR 4.8 Billion Threshold - 2011

This phenomenon has been occurring since 2013, as shown in fig. 7 , caused presumptive tax implementation ( $1 \%$ on turnover base) in July 2013. From 2013 to 2016, there is negative bunching phenomenon above the threshold in pooled data analysis, but there isn't in the previous period (2011 - 2012). Annual based analysis shows the same phenomenon as shown in Table 1.

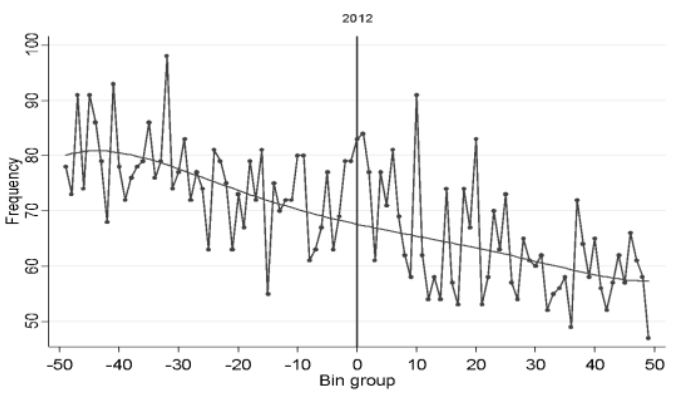

Figure 6. Annual Firms Turnover Distribution around IDR 4.8 Billion Threshold - 2012
This may highlight that the negative bunching phenomenon occurs due to the enactment of the presumptive tax policy. Firms responded to the presumptive tax policy immediately, after the policy implementation. This is indicated by changes in the distribution patterns of companies that are quite different between 2012 and 2013. Negative bunching appears immediately after policy is implemented which means that the company immediately adjusts to the enactment of policies to obtain the lowest tax burden.

The differences patterns over years can be concluded that SME's taxpayers view this presumptive tax policy scheme as a burden and frightened factor as if they would be the object of tax audit in a way not comply to this new tax policy scheme.

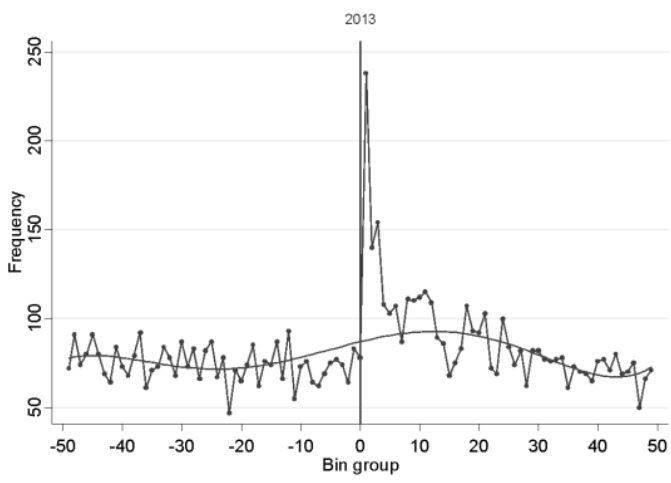

Figure 7. Annual Firms Turnover Distribution around IDR 4.8 Billion Threshold - 2013

Besides, firms tend to maximize their profit by managing which tax reporting schemes would give less tax burden. This presumptive tax scheme does not concern about the firms' expenses over a year and generalizes all firms have same cost to profit ratio. Thus, these graphics show that the new presumptive tax policy scheme 

does not achieve its goals just as explained before.

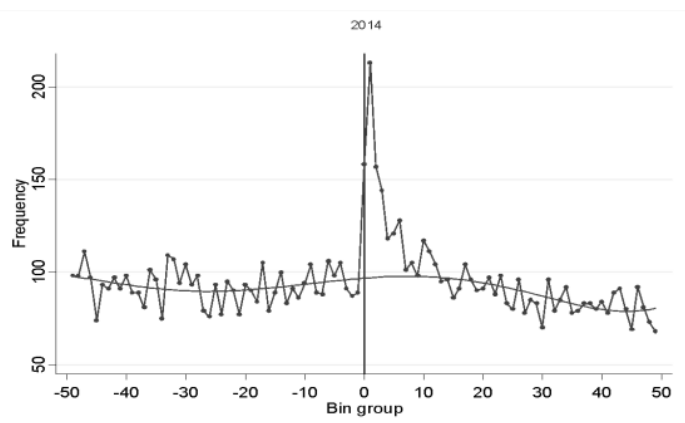

Figure 8. Annual Firms Turnover Distribution around IDR 4.8 Billion Threshold - 2014

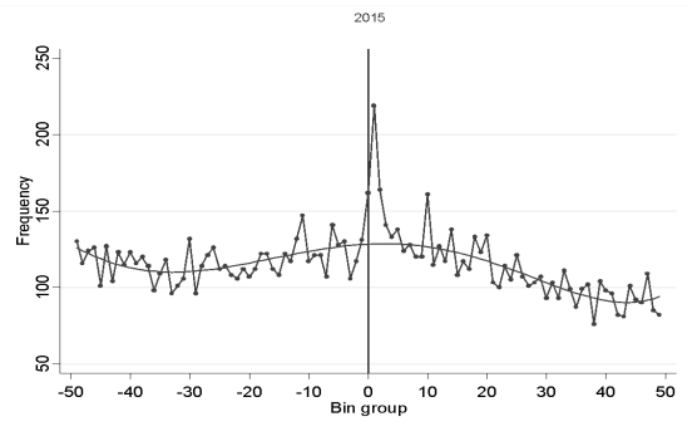

Figure 9. Annual Firms Turnover Distribution around IDR 4.8 Billion Threshold - 2015

The pattern of firms' distribution whose sales/turnover below the threshold increases naturally in the first two-year observations. These firms tend to have bunching phenomenon in order to gain lower tax burdens such as the cost of bookkeeping, tax reporting, and else. The pattern of firms' distribution between 2013 and 2016 shows consistency, which means that firms respond to this presumptive tax policy continuously. Over time between 2013 and 2016, the number of firms that are below the threshold has increased slowly. This shows that some firms are returning to behave normally like times before the threshold and the presumptive tax policy.

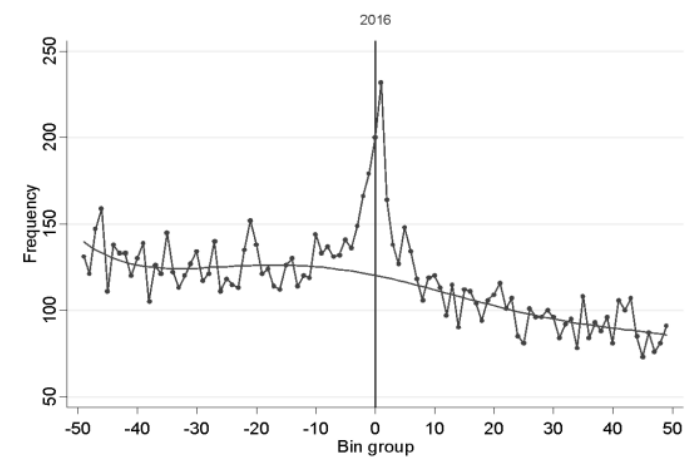

Figure 10. Annual Firms Turnover Distribution around IDR 4.8 Billion Threshold - 2016

By observing the negative bunching pattern from 2014 until 2016 as shown in Figure 8, 9, and 10, it can be seen that the lower the negative bunching, the more the bunching left over threshold. This phenomenon has ensued since 2014 because of another tax policy at turnover value as IDR 4.8 million. It is VAT threshold policy at the same turnover value. It causes varied firms' response regarding two thresholds at the same value. Firm tends to do negative bunching regarding the presumptive tax policy and positive bunching regarding the VAT threshold. These policies induce two opposite responses. Firms which consider the income tax burden more, would choose to do negative bunching regarding the presumptive tax policy. Yet firms which consider the VAT burden more, would do positive bunching regarding the VAT threshold policy. Despite of the previous graphic analysis, this study also analyzes by employing the bunching estimation initiated by Chetty et al. (2011). As shown in the graphic analysis, the bunching 
estimation is the negative bunching, the cumulation of firms in the area after the threshold. Table 1 shows the estimation result from two data models as pooled data model and annual data model. Observation is the number of the observed firms in this study.

The increase of the observed firms' number over the years is caused by several factors as follows, (1) the increasing firms' scale, (2) the increasing number of registered firms in tax system, and (3) the improvement of firms' tax reporting compliance. B shows the number of firms identified doing bunching acquired by the differences between actual firms' distribution and counterfactual firms' distribution in the midst of threshold and upper limit. The pooled data model shows that a bunching phenomenon happens above the threshold then known as negative bunching phenomenon based on $b$ value. In the two-period before the presumptive tax policy implemented, there are 63 firms indicated doing bunching compared to 1,982 firms below the counterfactual curve with the standard error as 0.4356 and the bunching estimation value as 0.5098 not significant in any level of $p$-value. However, in the four-period after the presumptive tax policy implemented, there are 1,201 firms indicated doing bunching compared to 6,891 firms below the counterfactual curve with the standard error as 0.2869 and the bunching value as 2.786 significant at the level of $1 \%$. The annual data model confirms the estimation result from the previous model that negative bunching phenomenon since the presumptive tax policy with threshold implemented. The data of 2011 shows the bunching estimation value as -0.1302 not significant in any level of $p$-value. Then in 2012, the bunching estimation value as 1.038 neither significant.

Table 1. Estimation Result in Negative Bunching around IDR 4.8 Billion Threshold

\begin{tabular}{lccccc}
\hline Year & Obs. & B & Under & b & Standard \\
& & & Counterfactual & & Error \\
\hline Pooled Data & & & & & \\
$2011-2012$ & 12,309 & 63 & 1,982 & 0.5098 & $(0.4356)$ \\
$2013-2016$ & 40,547 & 1,201 & 6,891 & $2.7860 * * *$ & $(0.2869)$ \\
Annual Data & & & & & \\
2011 & 5,431 & -7 & 362 & 1.0380 & $(0.6353)$ \\
2012 & 6,878 & 71 & 449 & $2.0110 * * *$ & $(0.3986)$ \\
2013 & 8,073 & 177 & 760 & $3.5410 * * *$ & $(0.5273)$ \\
2014 & 9,364 & 364 & 618 & $1.2020 * * *$ & $(0.4356)$ \\
2015 & 11,406 & 153 & 894 & $4.4360 * * *$ & $(0.5371)$ \\
2016 & 11,704 & 528 & 2,860 & & \\
\hline
\end{tabular}


Since the implementation of the presumptive tax policy with $1 \%$ flat tax rate based on turnover value in the mid year of 2013, there has been negative bunching phenomenon around threshold (IDR 4.8 million). The data of 2013 shows that the bunching estimation on the right side of threshold is 2.011 significantly at the level of $1 \% p$-value with 177 firms identified doing negative bunching. The data of 2014 shows that the bunching estimation value is 3.541 at $1 \%$ significance level with 364 firms indicated doing negative bunching. For the year of 2015, the bunching estimation value is $\mathbf{1 . 2 0 2}$ at $99 \%$ confidence level with 153 firms identified doing negative bunching. In the last year of observations, the data shows that the bunching estimation value is 4.436 at $99 \%$ confidence level with 528 firms doing negative bunching. The firms are able to easily choose between the lower area and the upper area of threshold. This occurs because of the absence of transitional provisions or "deadline" in the policy legal basis. There are several ways for firm to do negative bunching. The formal way likes spurring its sales to get more turnover value above threshold. The informal way is easier likes overreporting turnover value. By doing these, firm pays little sacrifice and gets more benefit later. Though this study is not able to identify which firm either do the formal way or the informal way. The identification has to be done through tax audit held by tax authorized. Beside that, just few of SME's taxpayers that becomes the concern and object of tax audit plan in Indonesia. SME's taxpayers obviously are become the concern of Indonesian government to be counseled and understood about tax obligations and to improve tax compliance.

The negative bunching phenomenon is empirically proved for Indonesian firms. Nevertheless, it occurs because the presumptive tax scheme implementation with certain threshold. It indicates that Indonesian firms try to over-report their sales/turnover in tax return so that they can gain a lower tax burden. It differs from what has been explained theoretically before firms tend to underreport or reduce their business operation. It implies that the presumptive tax scheme on turnover base gives more tax burden rather than the normal corporate income tax for firms with a turnover value around the threshold.

Hence, the original objectives of presumptive tax scheme implementation are unable to be achieved.

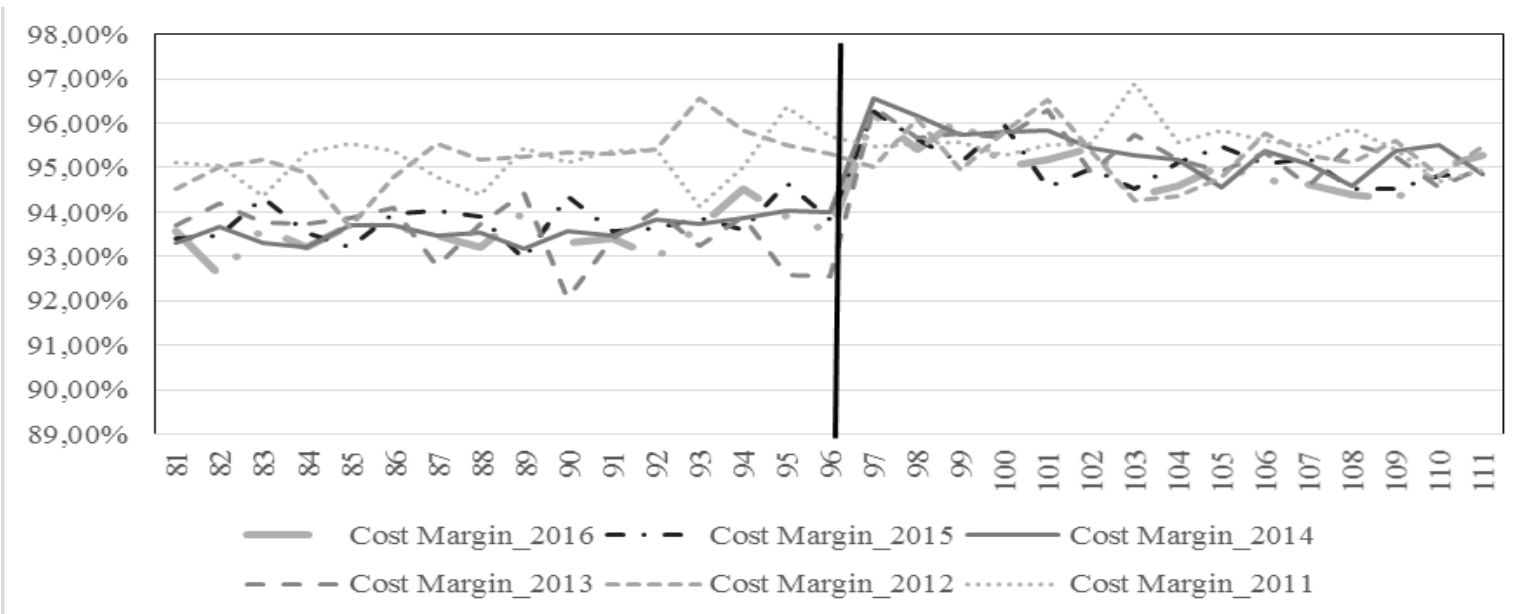

Figure 11. Firm's Cost to Sale Ratio in IDR 5o Billion Bin 
As an economic agent, firms maximize its profit almost in every condition. Corporate income tax is one factor that decreases profit. Normal corporate income tax is $25 \%$ on profit base, but there is a facility to reduce the tax rate to $12.5 \%$ on profit base with the condition that its annual turnover does not exceed IDR 50 billion. Since 2013, firms that have turnover value, not above IDR 4.8 billion can use presumptive tax scheme on turnover base.

Firms would do negative bunching when $t_{1}<t_{2}$ because of the lower tax burden. It implies that tax payable of presumptive tax $\left(t_{2}\right)$ scheme is higher than of normal corporate income $\operatorname{tax}\left(t_{1}\right)$. The firm would do negative bunching by increasing its sales in other positive ways or over-reporting its sales in a negative way. This kind of schemes is relatively safe since there is no sanction on over-reporting income or sales eventhough it would bias the country' economic indicators. To fulfill this condition, the firm's cost ratio to turnover is very likely to affect its decision.

$t_{1}<t_{2}$

$0.125[s-C]<0.01 s$.

$0.125 C>(0.125-0.01) s$

$C>\frac{0.115}{0.125} S$

$\frac{\mathrm{c}}{\mathrm{s}}>0.92$.

A firm that has cost to sales ratio of more than 0.92 would do negative bunching in order to obtain lower tax burdens. Before the implementation of one-percent presumptive tax policy, the average cost to sales ratio of Indonesian firms is 0.95. As shown in figure. 4 , the average cost to sales ratio of Indonesian firms around IDR 4.8 billion is actually higher than 0.92 so that firms with cost to sales ratio more than 0.92 would have an incentive to do negative bunching. This phenomenon explains why the negative bunching phenomenon happens in case of Indonesian corporate income tax regarding its one-percent presumptive tax policy implementation.

This study differs from other countries' studies that shows the positive bunching phenomenon in the area below the threshold. The various factors such as tax rates, tax administration system, and firm characteristics cause the diversity of studies' results. The implementation of various tax rates such as normal tax rate and presumptive tax rate could cause the different real response. The higher normal tax rate and the lower presumptive tax rate, the higher the bunching phenomenon probability. Regarding the average cost to sale ratio of Indonesian firms around 95\%, the optimal tax rate of the presumptive tax policy with certain threshold (IDR 4.8 billion) which does not cause the bunching phenomenon is around $0.6 \%$. Whether its tax rate is too high, firms tend to choose normal tax rate rather than its tax rate in order to gain lower tax burdens. Tax rate of $0.6 \%$ might be decrease the potency of negative bunching phenomenon, but it does not ensure the optimality of corporate income tax revenue. To maximize income tax revenue, there must be several factors considered besides tariffs, but also the amount of the threshold value (Brashares, Knittle, Silverstein, \& Yuskavage, 2014).

The effect of negative bunching would be different to the theoretical firm distribution figure as shown in the previous study (Almunia \& Lopez-Rodriguez, 2015; Best et al., 2015; Chetty et al., 2011; Fack \& Landais, 2016; Gebresilasse \& Sow, 2015; Harju, Matikka, \& Rauhanen, 2016; Heide \& Ardal, 2017; Kleven, 2016; le Maire \& Schjerning, 2013; Saez, 2010). When the negative bunching happens, the figure would be as follows excess mass is on the right side and the missing mass is on the left side of the threshold. 
Tax policy occasionally causes the bunching phenomenon below threshold (Kanbur \& Keen, 2014). There would be bunching phenomenon or not relatively depends on several factors such as compliance cost, supervision of tax authorized, etc. Firm as economic agent would maximize its profit for certain by choosing the lower tax burden. Thus, firm almost always responses the tax policy by which maximizes its profit.

\section{CONCLUSION}

susceptible to the implementation of tax policy. Firms would respond by choosing some ways which have lower tax burden. Firms respond to presumptive tax scheme with a certain threshold (IDR 4.8 billion) by doing negative bunching such as actively holding its sales to go above the threshold. Bunching occurs from 2013 to 2016 when the presumptive tax policy implemented. Firms are actively doing bunching when there is an incentive under the policy scheme implemented. While at the time the incentive is gone, firms which originally specialize in bunching would relax its reported income, approaching its actual sales/turnover or optimal capabilities in sales/turnover.

This phenomenon implies that firms choose to remain above the threshold because of the lower the tax burden in normal corporate income tax. Firms' decision to do a negative bunching depends on how big their cost to sale ratio which affect its tax burdens. The implementation of presumptive tax policy on turnover base is merely to be a consideration for sales/turnover reporting behavior.

\section{REFERENCE}

Adams, C., \& Webley, P. (2001). Small Business Owners' Attitudes on VAT Compliance in The UK. Journal of Economic Perspectives, 22, 195-216. https://doi.org/10.1016/So167-4870(o1)ooo29-o
Almunia, M. (2013). Size-Dependent Policies and Firm Behavior. University of California, Berkeley.

Almunia, M., \& Lopez-rodriguez, D. (2018). Under the Radar: The Effects of Monitoring Firms on Tax Compliance. American Economic Journal: Economic Policy, 10(1), 1-38.

Bastani, S., \& Selin, H. (2014). Bunching and non-bunching at kink points of the Swedish tax schedule. Journal of Public Economics, 109, 36-49. https://doi. org/10.1016 /j.jpubeco.2013.09.010

Baumeister, R. F. (1982). A self-presentational view of social phenomena. Psychological Bulletin, 91(1), 3-26. https://doi.org/10.1037/0033-2909.91.1.3

Best, M. C., Brockmeyer, A., Kleven, H. J., Spinnewijn, J., \& Waseem, M. (2015). Production versus Revenue Efficiency with Limited Tax Capacity: Theory and Evidence from Pakistan. Journal of Political Economy, 123(6), 1311-1355. https://doi.org/ 10.1086 1683849

Best, M. C., \& Kleven, H. J. (2017). Housing Market Responses to Transaction Taxes: Evidence From Notches and Stimulus in the U.K. Review of Economic Studies, 85(1), 1-37. https://doi.org/ $10.1093 / \mathrm{restud} / \mathrm{rdx032}$

Brashares, E., Knittle, M., Silverstein, G., \& Yuskavage, A. (2014). Calculating the Optimal Small Business ExemptionThreshold for a U.S. VAT. National Tax Journal, 67(2), 283-320. https://doi.org /10.17310/ntj. 2014.2.01

Chetty, R., Friedman, J. N., Olsen, T., \& Pistaferri, L. (2011). Adjustment Costs, Firm Responses, and Micro vs. Macro Labor Supply Elasticities: Evidence from Danish Tax Records. The Quarterly Journal of Economics, 126(2), 749-804. https://doi.org/10.1093 /qje/qjro13

Chetty, R., Guren, A., Manoli, D., \& Weber, A. (2011). Are micro and macro labor supply elasticities consistent? A review of evidence on the intensive and extensive margins. American Economic Review (Vol. 101, pp. 471-475). https://doi.org/ 10.1257/aer.101.3.471

Clair, T. S., \& Cook, T. D. (2015). Difference-in-Differences Methods in Public Finance. National Tax Journal, 68(2), 319-338. https://doi.org/10.17310/ntj.2015.2.04

Dwenger, N., Kleven, H., Rasul, I., \& Rincke, J. (2016). Extrinsic and intrinsic motivations for tax compliance: Evidence from a field experiment in Germany. American Economic Journal: Economic Policy, 8(3), 203-232. https://doi.org /10.1257/pol. 20150083

Fack, G., \& Landais, C. (2016). The effect of tax enforcement on tax elasticities: Evidence from charitable 
contributions in France. Journal of Public Economics, 133, 23-40. https://doi.org/10.1016/ j.jpubeco.2015.10.004

Gebresilasse, M. M., \& Sow, S. (2015). Firm Response to VAT Registration Threshold in Ethiopia. Columbia University.

Harju, J., \& Matikka, T. (2016). The elasticity of taxable income and income-shifting: what is "real" and what is not? International Tax and Public Finance, 23(4), 640-669. https://doi.org/10.1007/ s10797-016-9393-4

Harju, J., Matikka, T., \& Rauhanen, T. (2016). The effects of size-based regulation on small firms: evidence from VAT threshold. CESifo Working Paper Series.

Heide, J. C., \& Ardal, K. O. (2017). Size Management at Regulatory Thresholds by Norwegian Companies. BI Norwegian Business School.

Hsieh, C.-T., \& Olken, B. A. (2014). The Missing "Missing Middle"; Source: The Journal of Economic Perspectives, 28(3), 89-108.

Huang, J., \& Rios, J. (2016). Optimal tax mix with income tax non-compliance. Journal of Public Economics, 144, 52-63. https://doi.org/10.1016 /j.jpubeco.2016.10.001

Kanbur, R., \& Keen, M. (2014). Thresholds, informality, and partitions of compliance. International Tax and Public Finance, 21(4), 536-559. https://doi.org/10.1007/s10797-014-9314-3

Ministry of Finance. PMK-197 / PMK.03 / 2015 concerning Amendments to Minister of Finance Regulation Number 68 / PMK.03 / 2010 concerning Limitation of Small Entrepreneurs in Value Added Tax (2013). Indonesia. Retrieved from http: // www. Sjdih.depkeu .go.id / fulltext / 2013/197 PMK .03 2013Per.HTM

Kleven, H. J., Knudsen, M. B., Kreiner, C. T., Pedersen, S., \& Saez, E. (2011). Unwilling or Unable to
Cheat? Evidence From a Tax Audit Experiment in Denmark. Econometrica, 79(3), 651-692. https://doi.org/10.3982/ECTA9113

Kleven, H. J., \& Waseem, M. (2013). Using Notches to Uncover Optimization Frictions and Structural Elasticities: Theory and Evidence from Pakistan. The Quarterly Journal of Economics, 128(2), 669-723. https://doi.org/10.1093/qje/qjtoo4.Advance

Kleven, H. J. (2016). Bunching. Annual Review of Economics, 8(1), 435-464. https://doi.org/10.1146 /annurev-economics-080315-015234

le Maire, D., \& Schjerning, B. (2013). Tax bunching, income shifting and self-employment. Journal of Public Economics, 107, 1-18. https://doi.org /10.1016/j.jpubeco.2013.08.002

Liu, L., \& Lockwood, B. (2015). VAT Notches. CEPR Discussion Papers, (May).

Organization for Economic Cooperation and Development. (2009). OECD Policy Roundtable Report.

Onji, K. (2009). The response of firms to eligibility thresholds: Evidence from the Japanese value-added tax. Journal of Public Economics, 93(5-6), 766-775. https://doi.org/10.1016/ j.jpubeco.2008.12.003

Pagano, P., \& Schivardi, F. (2003). Firm size distribution and growth. Scandinavian Journal of Economics, 105(2), 255-274. https://doi.org/10.1111/1467- 9442.to1 -100008

Saez, E. (2010). Do Taxpayers Bunch at Kink Points? American Economic Journal: Economic Policy, 2(August), 180-212.

Slemrod, J. (1990). Optimal Taxation and Optimal Tax Systems. Journal of Economic Perspectives, 4(1), 157178. https://doi.org/10.1257/jep.4.1.157

Yasuda, T. (2005). Firm growth, size, age and behavior in Japanese manufacturing. Small Business Economics, 24(1), 1-15. https://doi.org/10.1007/s11187-005-7568-y. 